\title{
Surgical time and complications of total transvaginal (total-NOTES), single-port laparoscopic-assisted and conventional ovariohysterectomy in bitches
}

\author{
[Tempo cirúrgico e das complicações entre as técnicas de ovário-histerectomia totalmente transvaginal (total- \\ NOTES), videoassistida com único portal e convencional em cadelas] \\ M.A.M. Silva ${ }^{1}$, G.H. Toniollo ${ }^{2}$, F.N. Flores ${ }^{3}$, C.A.A. Valadão ${ }^{2}$, R.M. Medeiros ${ }^{2}$, \\ D.J. Cardilli ${ }^{2}$, A.P. Gering ${ }^{2}$, P.P.M. Teixeira ${ }^{4}$, G.M.C. Serafini, \\ A.S. Coutinho-Júnior ${ }^{5}$, R.N. Libardoni ${ }^{5}$, M.V. Brun ${ }^{5}$ \\ ${ }^{1}$ Universidade de Passo Fundo - UPF - Passo Fundo, RS \\ ${ }^{2}$ Universidade Estadual Paulista "Júlio de Mesquita Filho" - FCAV-UNESP - Jaboticabal, SP \\ ${ }^{3}$ Centro de Ciências Agrárias - Universidade Federal de Roraima (UFRR) - Boa Vista, RR \\ ${ }^{4}$ Universidade Estadual do Centro-Oeste - UNICENTRO - Guarapuava, PR \\ ${ }^{5}$ Centro de Ciências Rurais - Universidade Federal de Santa Maria - CCR-UFSM - Santa Maria, RS
}

\begin{abstract}
The recently developed minimally invasive techniques of ovariohysterectomy $(\mathrm{OVH})$ have been studied in dogs in order to optimize their benefits and decrease risks to the patients. The purpose of this study was to compare surgical time, complications and technical difficulties of transvaginal total-NOTES, singleport laparoscopic-assisted and conventional OVH in bitches. Twelve bitches were submitted to totalNOTES (NOTES group), while 13 underwent single-port laparoscopic-assisted (SPLA group) and 15 were submitted to conventional OVH (OPEN group). Intra-operative period was divided into 7 stages: (1) access to abdominal cavity; (2) pneumoperitoneum; approach to the right (3) and left (4) ovarian pedicle and uterine body (5); (6) abdominal or vaginal synthesis, performed in 6 out of 12 patients of NOTES; (7) inoperative time. Overall and stages operative times, intra and postoperative complications and technical difficulties were compared among groups. Mean overall surgical time in NOTES (25.7 \pm 6.8 minutes) and SPLA $(23.1 \pm 4.0$ minutes) groups were shorter than in the OPEN group $(34.0 \pm 6.4$ minutes $)(P<0.05)$. The intraoperative stage that required the longest time was the approach to the uterine body in the NOTES group and abdominal and cutaneous sutures in the OPEN group. There was no difference regarding the rates of complications. Major complications included postoperative bleeding requiring reoperation in a bitch in the OPEN group, while minor complications included mild vaginal discharge in four patients in the NOTES group and seroma in three bitches in the SPLA group. In conclusion, total-NOTES and SPLA $\mathrm{OVH}$ were less time-consuming then conventional $\mathrm{OVH}$ in bitches. All techniques presented complications, which were properly managed.
\end{abstract}

Keywords: canine, spay, laparoscopy, operative time, transvaginal approach

\section{RESUMO}

O emprego de novas técnicas minimamente invasivas de ovário-histerectomia (OHE) vem sendo estudado em cães com o intuito de otimizar seus benefícios e reduzir os riscos aos pacientes. $O$ presente estudo objetivou comparar o tempo cirúrgico, as complicações e dificuldades técnicas entre as abordagens por total-NOTES transvaginal, videoassistida com único portal e por celiotomia para ovário-histerectomia (OVH) em cadelas. Foram operados 12 animais por total-NOTES (grupo NOTES), 13 pela técnica videoassistida (grupo SPLA) e 15 pela técnica convencional (grupo OPEN). O período intraoperatório foi dividido em sete etapas: (1) acesso à cavidade abdominal; (2) criação do pneumoperitônio; abordagem ao pedículo ovariano direito (3), esquerdo (4) e ao corpo uterino (5); (6) síntese abdominal ou vaginal, realizado em seis de 12 pacientes do grupo NOTES; (7) tempo inoperante. Os parâmetros

Recebido em 22 de fevereiro de 2014

Aceito em 7 de agosto de 2014

E-mail: silvamam@gmail.com 
avaliados foram o tempo cirúrgico total e de cada etapa intraoperatória, a frequência de complicações intra e pós-operatórias e dificuldades técnicas. O tempo cirúrgico total médio dos grupos NOTES (25,7 $\pm 6,8$ minutos) e SPVA (23,1 $\pm 4,0$ minutos) foram menores que o do grupo OPEN (34,0 $\pm 6,4$ minutos) $(P<0.05)$. A etapa intraoperatória que demandou maior tempo de execução foi a abordagem ao corpo uterino para o grupo NOTES, e síntese abdominal e cutânea para o grupo OPEN. Uma cadela do grupo OPEN necessitou de reintervenção para controle de hemorragia como complicação maior, e três cadelas do grupo SPVA apresentaram seroma de ferida cirúrgica como complicações menores. Concluiu-se que as técnicas de total-NOTES e SPLA apresentaram menor tempo cirúrgico que a abordagem convencional de OVH em cadelas. Todas as técnicas apresentaram complicações que foram adequadamente manejadas.

Palavras-chave: caninos, castração, laparoscopia, tempo operatório, abordagem transvaginal

\section{INTRODUCTION}

The search for less a invasive surgical technique is one of the main efforts in current surgical researches. All surgical techniques in development require experience and time, which is referred to as a learning curve, in order to minimize risks to patients and improve their benefits in comparison to traditional approaches (Hardie, 2006).

Several laparoscopic and laparoscopic-assisted techniques of ovariohysterectomy (OVH) were described in bitches (Brun et al., 2000; Devitt et al., 2005; Hancock et al., 2005). The main benefits of minimally invasive surgery in bitches are less pain, better convalescence, shorter hospital stay, less bleeding and reduced wound complications (Brun et al., 2000; Malm et al., 2004; Devitt et al., 2005; Hancock et al., 2005). In opposition, limitations include the learning curve, increased surgical time and cost of the equipment (Malm et al., 2004).

Laparoscopic and laparoscopic-assisted $\mathrm{OVH}$ were described using four port (Brun et al., 2000; Malm et al., 2004), three (Mayhew and Borown, 2007), two port (Dupré et al., 2009) and singleport approach (Dupré et al., 2009; Silva et al., 2011). Natural orifice transluminal endoscopic surgery (NOTES) is one of the newest concepts in minimally invasive surgery that brings promising results over conventional and other endosurgical spay techniques (Freeman et al., 2009; Brun et al., 2011). A transvaginal hybridNOTES technique was described (Brun et al., 2011). An umbilical trocar was established, followed by laparoscopic-assisted insertion of an instrument port into the abdominal cavity through the vaginal cul de sac, for hemostasis and resection of the ovarian pedicles.
A feasibility study of ovariohysterectomy performed using a single transvaginal port in bitches, which was called pure-NOTES OVH, was performed (Silva et al., 2012). The main advantages of the pure-NOTES OVH were the absence of need for special wound care, decreased surgical trauma and lack of complications of the surgical wound, while the main limitations included poor instrument reach in larger dogs and large amount of fat tissue surrounding the ovarian bursa and pedicle in some patients. Nevertheless, the real advantages and limitations were poorly discussed by the authors. Additionally, the authors affirmed that surgical time of pure-NOTES OVH was closely similar to those of other laparoscopic or laparoscopic-assisted techniques. However, intra-operative aspects and potential complications of total transvaginal NOTES (total-NOTES) was not prospectively compared to other OVH techniques in the canine specie.

Therefore, the purpose of this study was to compare surgical time and complication rates of total-NOTES, single-port laparoscopicassisted and conventional approaches for ovariohysterectomy in bitches.

\section{MATERIAL AND METHODS}

This research was approved by the Council for Ethics and Animal Welfare of the School of Agrarian and Veterinary Sciences of the São Paulo State University (FCAV/UNESP, Protocol CEBEA No. 019211-08).

The inclusion criteria for patients was based on physical examination, vaginal smear, abdominal ultrasonography, complete hemogram and serum alanine aminotransferase (ALT) and creatinine. 
Only patients presenting normal parameters and anestrus were admitted. Forty mongrel bitches weighting $14 \pm 5.2 \mathrm{~kg}$ (range $8.9-25.0 \mathrm{~kg}$ ) matching the inclusion criteria were evaluated.

A prospective study to compare three techniques of OVH in bitches was performed: (1) Group NOTES was composed by 12 bitches submitted to total-NOTES OVH; (2) group SPLA, consisting of 13 bitches submitted to single-port laparoscopic-assisted $\mathrm{OVH}$; and group OPEN was constituted by 15 patients subjected to conventional celiotomy OVH.

Patients were hospitalized 24 hours prior to surgery. Food was withheld for 10 hours prior to surgery. The dogs were given an association of acepromazine $\quad(0.02 \mathrm{mg} / \mathrm{kg}), \quad$ midazolam $(0.4 \mathrm{mg} / \mathrm{kg})$ and morphine sulphate $(0.5 \mathrm{mg} / \mathrm{kg})$ intramuscularly for premedication. Anesthesia was induced following 20 minutes using propofol $(6 \mathrm{mg} / \mathrm{kg}$, IV) and maintained using isoflurane vaporized in $100 \%$ oxygen, in semiclosed circuit, following endotracheal intubation.

For the total-NOTES OVH the patients were positioned in dorsal recumbency and cranially directed to the laparoscopic equipment. The abdomen was aseptically prepared for surgery and antisepsis of the vaginal and vulva were carried out using povidone-iodine $0.5 \%$ solution diluted in sterile normal saline, as described previously (Brun et al., 2011, Silva et al., 2012). Bladder was emptied using 6-8 fr. urinary catheter and urine output was measured during surgery.

The vulva was opened using a vaginal speculum and the dorsal vaginal mucosa fold was grasped with a curved Kelly forceps at the cul de sac area. The vaginal mucosa was gently pulled outside the vaginal canal. Three additional hemostats were used to grasp the mucosa in a "four-leaf clover" fashion and improve mucosal exposition for incision. In 6 out of 12 bitches, a 0-UPS polyglecaprone 25 stay suture was applied to the mucosa prior to incision, which remained in place during surgery. Such maneuver was performed so the vaginal incision could be pulled out of the vagina and sutured at the end of the procedure. Following a $12-14 \mathrm{~mm}$ incision of the mucosa using a scalpel, the submucosa layer was bluntly dissected using curved Metzenbaum scissors. The tip of a $12 \mathrm{~mm}$
$10 \mathrm{~cm}$ long trocar (Endopath Xcel Optical Trocar $^{\circledR}$, Ethicon Endosurgery, São Paulo, SP, Brazil) was positioned within the incision. The hemostats were released as the trocar was gently pushed into the vaginal canal through the incision in a $180^{\circ}$ clockwise and counterclockwise axial rotational motion, so that the vaginal serosa could be perforated and the abdominal cavity entered. Abdominal entry was confirmed by external palpation and endoscopic view of the omentum and/or pelvic fat through the trocar. If the serosa layer was not completely perforated using the trocar obturator, the tip of the telescope was gently pushed against the serosa so that it could be ruptured.

A $10 \mathrm{mmHg} \mathrm{CO}_{2}$ pneumoperitoneum was created using a 1-2 L/min flow rate and the total-NOTES $\mathrm{OVH}$ was performed using the technique described by Silva et al. (2012). A $10 \mathrm{~mm}$ straight-angled telescope with a $6 \mathrm{~mm}$ working channel (26038 AA - Karl Storz ${ }^{\mathrm{TM}}$, Germany. Distributed by H. Strattner, São Paulo, SP, Brazil) and a $5 \mathrm{~mm}$ diameter, $42 \mathrm{~cm}$ long bipolar coagulation and cutting forceps (Lina Tripol Poweblade ${ }^{\mathrm{TM}}$, LINA Medical Inc., Denmark. Distributed by WEM Electronic Equipment Ltd., Ribeirão Preto, SP, Brazil) were used. Following resection of the uterus and ovaries, vaginal incision was not sutured in the first 6 cases in the procedure. On the other 6 patients, the stay sutures were pulled out of the vagina and the incision was exposed. The vaginal incision was sutured using the Ford interlocking pattern, with 3-0 polyglecaprone 25 thread. The vaginal stay suture was removed and the patients were able to convalesce.

The single-port laparoscopic-assisted $\mathrm{OVH}$ followed the same patient preparation and positioning, basic principles, and instruments used for the total-NOTES approach. The technique described by Silva et al. (2011) was used, except for the hemostasis of the uterine body and vessels, which was carried out using bipolar coagulation and cut instead of ligation with suture thread. The incision was closed in two layers using 0-USP polyglecaprone 25 thread, cross mattress pattern on the linea alba, and 3-0 USP nylon, interrupted horizontal mattress suture on the skin.

For the conventional OVH, the patients were positioned and the surgical field was aseptically 
prepared as for the other groups. A $7 \mathrm{~cm}$ standard celiotomy started right caudal to the umbilicus was carried out. The traditional three-clap technique (MacPhail, 2013) was used. Polyglecaprone 25 0-USP was used for ligation of the ovarian pedicles and uterine body and vessels. The abdomen was sutured using 0 -USP polyglecaprone 25 thread, interrupted cross mattress pattern. The dead space was reduced using 3-0 USP polyglecaprone 25 thread and skin was sutured using 3-0 USP nylon thread, interrupted horizontal mattress pattern.

Following extubation, all patients were conducted to the recovery/assessment room and received morphine $(0.25 \mathrm{mg} / \mathrm{kg})$ during the first 24 hours in 6-hour intervals or according to the need for rescue analgesia using the numerical rating scale (NRS) criteria for pain assessment, as previously described (Holton et al., 1998; Imagawa et al., 2011). The patients were discharged following 24 hours of surgery if no early post-op complications were noted. Wound care was performed twice a day using sterile normal saline and a wound protection collar was put on all patients until the skin sutures were removed, on the $10^{\text {th }}$ day post-op.

The surgical procedures were divided into seven stages/steps in order to evaluate surgical time: (1) access to the abdominal cavity; (2) establishment of the $10 \mathrm{mmHg}$ pneumoperitoneum, except for the OPEN group; (3) approach of the right pedicle, which involved manipulation, prophylactic hemostasis and resection; (4) approach of the left pedicle; (5) approach to the uterine body, which involved manipulation, prophylactic hemostasis, resection and repositioning of the uterine stump within the abdominal cavity; (6) synthesis, time spent for suturing the abdominal wall and skin in OPEN and SPLA groups or the vaginal incision in the NOTES group; (7) inactive/inoperative time, which involved time spent preparing sutures, adjustment of equipment and changes in patient positioning during surgery, if required. Overall and stages surgical time were recorded in all groups.

Intraoperative technical difficulties and complications during surgery were recorded. All patients were closely evaluated in the first 24 hours for early signs of complications if any occurred. The clinical evaluations were performed at $1,2,4,8,16$ and 24 hours after extubation. The dogs were followed up on days 3, 7, 10 and 15 post-op. Moreover, the owners were advised to contact if complications occurred at any time point beyond the scheduled appointments.

All statistical analyses were performed using statistical software (GraphPad Prism ${ }^{\mathrm{TM}}$, version 4.0 for Windows, GraphPad Software, San Diego, CA, USA). Mean and SD values of weight, overall and stage time were calculated. One-way ANOVA and Tukey post-test were used to compare the effect of surgery and surgical stage on time. Chi-square test was used to compare the rate of intraoperative and post-op complications among groups. For all comparisons, significance was set at $\alpha=0.05$.

\section{RESULTS}

Mean $( \pm$ SD) weight was $14.1( \pm 2.1) \mathrm{kg}, 12.6( \pm$ $6.0) \mathrm{kg}$ and $15.1( \pm 8.0) \mathrm{kg}$ for the NOTES, SPLA and OPEN groups, respectively $(P>0.05)$. OPEN group $(34.0 \pm 6.4$ minutes $)$ presented longer surgical time $(P<0.05)$ than NOTES $(25.7 \pm 6.8$ minutes $)$ and SPLA $(23.1 \pm 4.0$ minutes) (Table 1). Time to access the abdominal cavity and for approaching the uterine body was longer in NOTES than in SPLA and OPEN $(P<0.05)$. The approach to the uterine body was the most time-consuming intraoperative stage in NOTES (7.1 \pm 5.4 minutes), while synthesis $(14.5 \pm 2.0$ minutes) was the most long-lasting step in OPEN $(P<0.05)$. Time was balanced among the intraoperative stages in SPLA $(P>0.05)$

Regarding intraoperative complications, there was no difference among groups $(P>0.05)$. There were two cases of mild venous hemorrhage due to incomplete coagulation of one of the ovarian pedicles (stage 3 or 4 ) in NOTES $(16.7 \%$ ) and two in SPLA (15.4\%). In all cases, additional coagulation was required to promote adequate hemostasis. There was partial rupture of the left uterine horn during traction for exteriorization through the vaginal incision in a bitch $(8.4 \%)$ from the NOTES group. In that case the left uterine horn was coagulated, resected and the stump was repositioned within the abdominal cavity. The trocar was reinserted and the right uterine horn was grasped and pulled out of the vagina along with the trocar cannula. The uterine 
body was then adequately exteriorized, coagulated/resected and repositioned within the abdominal cavity. In the OPEN group there were two cases of accidental rupture of the left ovarian pedicle (stage 4) and consequent arterial hemorrhage during traction for exposure and ligation $(13.4 \%)$. In those cases, enlargement of the incision was required for adequate clamping and ligation of the bleeding stump.

Table 1. Overall and stage surgical times (mean \pm SD) of total-NOTES (NOTES), single-port laparoscopic-assisted (SPLA) and conventional (OPEN) ovariohysterectomy in bitches.

\begin{tabular}{|c|c|c|c|c|c|c|c|c|c|c|}
\hline \multirow{2}{*}{ Group } & \multirow{2}{*}{$\mathrm{N}$} & \multirow{2}{*}{$\begin{array}{l}\text { Weight } \\
(\mathrm{Kg})\end{array}$} & \multicolumn{7}{|c|}{ Mean $( \pm \mathrm{SD})$ time of intraoperative stages (min.)* } & \multirow{2}{*}{$\begin{array}{c}\text { Overal } \\
\text { time }\end{array}$} \\
\hline & & & 1 & $2^{\S}$ & 3 & 4 & 5 & 6 & 7 & \\
\hline NOTES & 12 & $\begin{array}{c}14.1 \\
( \pm 2.1)\end{array}$ & $\begin{array}{c}4.8^{\mathrm{a}} \\
( \pm 2,0)\end{array}$ & $\begin{array}{c}1.3 \\
( \pm 0.3)\end{array}$ & $\begin{array}{c}3.5 \\
( \pm 2.1)\end{array}$ & $\begin{array}{c}3.3 \\
( \pm 1.9)\end{array}$ & $\begin{array}{c}7.1^{\mathrm{ab}} \\
( \pm 5.4)\end{array}$ & $\begin{array}{c}4.2 \\
( \pm 0.9)^{*}\end{array}$ & $\begin{array}{c}3.6 \\
( \pm 1.5)\end{array}$ & $\begin{array}{c}25.7 \\
( \pm 6.8)\end{array}$ \\
\hline OPEN & 15 & $\begin{array}{c}15.1 \\
( \pm 8.0)\end{array}$ & $\begin{array}{c}2.3 \\
( \pm 0.5)\end{array}$ & - & $\begin{array}{c}4.1 \\
( \pm 1.6)\end{array}$ & $\begin{array}{c}4.5 \\
( \pm 2.1)\end{array}$ & $\begin{array}{c}3.8 \\
( \pm 0.8)\end{array}$ & $\begin{array}{l}14.5^{\mathrm{ab}} \\
( \pm 2.0)\end{array}$ & $\begin{array}{c}4.8 \\
( \pm 1.5) \\
\end{array}$ & $\begin{array}{c}34.0 \\
( \pm 6.4)\end{array}$ \\
\hline
\end{tabular}

Surgical stages: (1) access to abdominal cavity; (2) establishment of the pneumoperitoneum. ${ }^{\S}$ Not compared among groups; (3) approach to the right ovarian pedicle; (4) approach to the left ovarian pedicle; (5) approach to the uterine body; (6) abdominal or vaginal synthesis. *Performed in 6 of 12 patients in NOTES; (7) Inoperative time. ${ }^{a} P<0.05$ among groups; ${ }^{\mathrm{b}} P<0.05$ within groups.

Regarding technical difficulties of execution of the total-NOTES OVH, the length of the trocar sheath/obturator was insufficient to perforate the vagina serosa and enter the abdominal cavity in 6 patients $(50 \%)$. The access to the abdominal cavity was completed by retrieving the obturator and gently advancing the tip of the telescope against the vaginal submucosa layer in a clockwise/counterclockwise motion so it could be penetrated. In one patient that had incomplete vaginal perforation during trocar insertion $(8.3 \%)$, exteriorization of both uterine horns through the vaginal incision was not possible. In that case, the left uterine horn and vessels were coagulated, resected and repositioned within the abdominal cavity. Thus, the trocar was repositioned for grasping and exteriorizing the right uterine horn. There were five cases of insufflation of the omental pouch $(41.7 \%)$, which remained temporarily adhered to the abdominal wall. The omentum was repositioned using the grasping forceps and surgery proceeded normally.

Technical difficulties during SPLA OVH included needle break within the abdominal cavity during suspension suture in one patient and need for enlargement of the prepubic incision from $13 \mathrm{~mm}$ to $25-30 \mathrm{~mm}$ for retrieval of the ovaries and uterus in two cases $(15.4 \%)$. The broken needle was adequately managed by pulling it out of the cavity through the trocar using the grasping forceps. During conventional $\mathrm{OVH}$, four bitches (26.7\%) required caudal extension of the celiotomy in order to approach the uterine body.

Regarding postoperative complications, four out of 12 bitches (33.3\%) presented mild serosanguineous vaginal discharge, which ceased spontaneously up to 24 hours in three patients and up to 72 hours in one patient. All of those patients belonged to the group of six bitches that received no suture of the vaginal incision, while none of the bitches that had the vaginal wound closed showed vaginal discharge at any time point $(p=0.0143)$. All patients in the NOTES group presented mild non-painful vulvar swelling for up to 3 days post-op, which were not considered potential complications. There were three cases $(23 \%)$ of seroma formation at the incision site in the SPLA group. One of those patients presented wound dehiscence. All patients belonging to the OPEN group presented mild painful wound inflammation that lasted for up to three days post-op, which were not considered major complications. One patient from the OPEN group presented early postoperative bleeding and required reoperation. Following two hours of the first surgery, an exploratory celiotomy was carried out and revealed a bleeding artery from the right uterine broad ligament, which was inadvertently torn and started bleeding in the early post-op period. The bleeding artery was properly ligated and the patient recovered uneventfully. There were no differences among groups concerning post-op complication rates $(p=0.167)$. 


\section{DISCUSSION}

This research revealed that endosurgical approaches for OVH can be less time consuming than conventional OVH. In contrast, laparoscopic $\mathrm{OVH}$ presented longer surgical time in comparison to conventional approach in other studies (Malm et al., 2004; Hancock et al., 2005). However, all steps were performed within the abdominal cavity in those procedures in those trials, which is more time-consuming (Gower and Mayhew, 2008). Both total-NOTES and SPLA OVH are laparoscopic-assisted procedures, as the uterine body and vessels are approached outside of the abdominal cavity, combining versatility and speed, as stated by others (Devitt et al., 2005; Gower and Mayhew, 2008). Furthermore, the short wound length in SPLA and NOTES groups resulted in less time elapsed for wound closure in comparison to the conventional technique, as shown in this study.

Overall operative time in NOTES $(23.5 \pm 4.0$ minutes) and SPLA $(25.7 \pm 6.8$ minutes $)$ were similar to the results described by Devitt et al. (2005) and Ataíde et al. (2010) regarding a twoport laparoscopic-assisted approach (20.8 and 28 minutes, respectively). Overall surgical time was $22.95( \pm 5.17)$ in the assessment of the learning curve of SPLA OVH (Silva et al., 2011). The single-port and two-port approaches were performed in 21.0 and 19.0 minutes, respectively, in another study (Dupré et al., 2009). The results of those researches were also comparable to those obtained in this study.

Time spent for conventional OVH was closely similar to those obtained in other trials (Hancock et al., 2005; Peeters and Kirpensteijn, 2011), while others have obtained operative times as short as 21.1 (Malm et al., 2004) and 18.6 minutes (Devitt et al., 2005). Synthesis was the most time-consuming stage of conventional $\mathrm{OVH}$, which evidently affected overall surgical time in comparison to the total-NOTES and SPLA approaches. Time elapsed for synthesis during conventional $\mathrm{OVH}$ was $15.5( \pm 1.5)$ minutes and overall procedure time was 35 minutes in a study (Peeters and Kirpensteijn, 2011). Such results were closely similar to those found in this research.

Although mild hemorrhage occurred in two patients from the NOTES group and in two dogs from the SPLA group, such complications were promptly controlled by applying additional bipolar coagulation. Those mild intraoperative complications were attributed to the large amount of fat tissue involving the ovarian pedicles in those patients, which impaired vessel sealing. The amount of adipose tissue on the ovarian pedicles is affected by age, body score and number of estral cycles. Moreover, fatty ovarian pedicles affect surgical time and imply risk factor for bleeding (Van Goethem et al., 2003). Port incision enlargement was also required in other studies, due to enlarged ovarian pedicles and bursa (Davidson et al., 2004; Malm et al., 2004).

Incomplete entrance to the abdominal cavity trough the vaginal incision and insufflation of the omental pouch during total-NOTES OVH were attributed to the short working length of the trocar. Despite time-consuming and technically challenging, those events did not affect the overall operative time, which were successfully managed without the need for conversion to celiotomy. We hypothesize that a $20-25 \mathrm{~cm}$ trocar sheath would be long enough to overcome the resistance of the vaginal submucosa and serosa layers and enter the abdominal cavity in a wide range of dogs. Nevertheless, further studies are required in order to test this hypothesis.

Port incision enlargement is occasionally required for retrieving the uterus from the abdominal cavity, due to enlarged adipose ovarian pedicles and bursa (Davidson et al., 2004; Hancock et al., 2005), as occurred in two patients of SPLA group. Moreover, hemorrhage is more likely to occur during the approach to fatty ovarian pedicles (Van Goethem et al., 2003). Otherwise, difficulty in exteriorizing the uterine body during conventional $\mathrm{OVH}$ was attributed to age. All patients that required incision enlargement were prepubertal bitches. An enlarged celiotomy may be required in prepubertal bitches, as the uterine body may be found more caudally in those patients (Peeters and Kirpensteijn, 2011; MacPhail, 2013). Incisions that encompass two-thirds of the length between the umbilicus and the pubis are usually wide enough in order to perform conventional ovariohysterectomy in bitches (MacPhail, 2013). On the other hand, the incision site was appropriate for approaching the uterine body in both total-NOTES and SPLA techniques, 
corroborating other trials (Silva et al., 2011; Silva et al., 2012).

Seroma formation was also a post-op complication of laparoscopic-assisted $\mathrm{OVH}$ in another study (Hancock et al., 2005), which probably occurred due to poor reduction of subcutaneous dead space. Davidson et al. (2004) described a case of early post-op hemorrhage in a bitch undergone conventional $\mathrm{OVH}$, which required reoperation, as occurred in this study. Hemorrhages from vessels of the mesometrium and uterine broad ligament can occur, although ligature fail is the main source of hemorrhage (Burrow et al., 2005; MacPhail, 2013). No postop hemorrhage was reported in both NOTES and SPLA groups following bipolar vessel sealing in this trial.

Despite no major complications occurring, nonclosure of the vaginal wound resulted in mild vaginal discharge in four out of six patients, while suturing avoided postoperative bleeding in all animals. That result revealed that synthesis of the vaginal wound should be considered for optimizing the benefits of the total-NOTES technique. Moreover, it is important to highlight that one of the most important benefits of the total-NOTES OVH concerns the surgical wound. The single-incision is located within the vaginal canal, which avoids complications, such as selftrauma, evisceration and the need for protection collars (Silva et al., 2012).

\section{CONCLUSION}

In conclusion, the transvaginal total-NOTES and single-port laparoscopic-assisted ovariohysterectomy presented shorter operative time in comparison to the conventional celiotomy approach, especially concerning time elapsed for synthesis. Regardless of the surgical technique, all complications were adequately managed. Although technically challenging, the totalNOTES OVH did not demanded special wound care.

\section{AKNOWLEDGEMENTS}

The authors would like to thank FAPESP (the São Paulo State Foundation for Research Support) for the financial support for this research (Processes 2008/56695-9 and 2009/14712-7), and WEM Electronic Equipment and Lina Medical for providing the Lina Tripol Powerblade ${ }^{\mathrm{TM}}$ forceps.

\section{REFERENCES}

ATAIIDE, M.W.; BRUN, M.V.; BARCELLOS, L.J.G. et al. Ovariosalpingohisterectomia vídeoassistida ou convencional em cadelas com o uso de Ligasure atlas ${ }^{\mathrm{TM}}$. Cienc. Rural, v.40, p.19741979, 2010.

BRUN, M.V.; SILVA-FILHO, A.P.F.; BECK, C.A.C. et al. Ovário-histerectomia em caninos por cirurgia laparoscópica. Braz. J. Vet. Res. Anim. Sci., v.37, p.480-485, 2000.

BRUN, M.V.; SILVA, M.A.M.; MARIANO, M.B. et al. Ovariohysterectomy in a dog by hybrid NOTES technique - a case report. Can. Vet. J., v.52, p.637-640, 2011.

BURROW, R.; BATCHELOR, D.; CRIPPS, P. Complications observed during and after ovariohysterectomy of 142 bitches at a veterinary teaching hospital. Vet. Rec., v.157, p.829-833, 2005.

DAVIDSON, E.B.; DAVID MOLL, H.; PAYTON, M. E. Comparison of laparoscopic ovariohysterectomy and ovariohysterectomy in dogs. Vet. Surg., v.33, p.62-69, 2004.

DEVITT, C.M.; COX, R.E.; HAILEY, J.J. Duration, complications, stress, and pain of open ovariohysterectomy versus a simple method of laparoscopic-assisted ovariohysterectomy in dogs. J. Am. Vet. Med. Assoc., v.227, p.921-927, 2005.

DUPRÉ, G.; FIORBIANCO, V.; SKALICKY, M. et al. Laparoscopic ovariectomy in dogs: comparison between single portal and two-portal access. Vet. Surg., v.38, p.818-824, 2009.

FREEMAN, L.J.; RAHMANI, E.Y.; SHERMAN, S. et al. Oophorectomy by natural orifice transluminal endoscopic surgery: feasibility study in dogs. Gastrointest. Endosc., v.69, p.1321-1332, 2009.

GOWER, S.; MAYHEW, P. Canine laparoscopic and laparoscopic-assisted ovariohysterectomy and ovariectomy. Compend. Cont. Educ. Vet., v.30, p.430-440, 2008.

HANCOCK, R.B.; LANZ, O.I.; WALDRON, D.R. et al. Comparison of postoperative pain after ovariohysterectomy by harmonic scalpelassisted laparoscopy compared with median celiotomy and ligation in dogs. Vet. Surg., v.34, p.273-282, 2005. 
HARDIE, E.M. Spaying: one technique no longer fits all. Compend. Cont. Educ. Vet., v.30, p.416-418, 2006.

HOLTON, L.; SCOTT, E.M.; NOLAN, A.M. et al. Comparison of three methods used for assessment of pain in dogs. J. Am. Vet. Med. Assoc., v.212, p.61-66, 1998.

IMAGAWA, V.H.; FANTONI, D.T.; TATARUNAS, A.C. et al. The use of different doses of metamizol for post-operative analgesia in dogs. Vet. Anaesth. Analg., v.38, p.385-393, 2011.

MACPHAIL, C.M. Surgery of the reproductive and genital systems. In: FOSSUM, T. W.; DEWEY, C.W.; HORN, C.V. et al. (Ed). Small animal surgery. 4.ed. Saint Louis: Elsevier Mosby, 2013. p.780-855.

MALM, C.; SAVASSI-ROCHA, P.R.; GHELLER, V.A. et al. Ovariohysterectomy: experimental and comparative study between laparoscopic and conventional approaches. Intraoperative phase. Arq. Bras. Med. Vet. Zootec., v.56, p.457-466, 2004.
MAYHEW, P.D.; BROWN, D.C. Comparison of three techniques for ovarian pedicle hemostasis during laparoscopic-assisted ovariohysterectomy. Vet. Surg., v.36, p.541-547, 2007.

PEETERS, M.E.; KIRPENSTEIJN, J. Comparison of surgical variables and short-term postoperative complications in healthy dogs undergoing ovariohysterectomy or ovariectomy. J. Am. Vet. Med. Assoc., v.238, p.189-194, 2011.

SILVA, M.A.M.; SANTOS-BATISTA, P.A.C.; POGIANNI, F.M. et al. Ovário-histerectomia vídeo-assistida com único portal em cadelas: estudo retrospectivo de 20 casos. Cienc. Rural, v.41, p.294-300, 2011.

SILVA, M.A.M.; TONIOLLO, G.H.; CRDOSO, K.C.F. et al. Pure-transvaginal natural orifice transluminal endoscopic surgery (NOTES) ovariohysterectomy in bitches: a preliminary feasibility study. Cienc. Rural, v.42, p.12371242, 2012.

VAN GOETHEM, B.E.B.J.; ROSENVELDT, K.W.; KIRPENSTEINJT, J. Monopolar versus bipolar electrocoagulation in canine laparoscopic ovariectomy: a nonrandomized, prospective, clinical trial. Vet. Surg., v.32, p.464-470, 2003. 